\title{
Towards Enhancing Science, Technology, Engineering, and Mathematics (STEM) Education; A Case for Higher Education in Africa.
}

\author{
Dr. Kehdinga George Fomunyam \\ Teaching and Learning Development Center, Mangosuthu University of Technology, Durban, South Africa.
}

\section{INTRODUCTION AND PROBLEM}

Higher education is learning that occurs at a university, college, polytechnic or institute beyond high school level. It is a phase of learning that is accomplished in colleges, universities, or academies usually after the completion of secondary education (igi-global.com, 2020). There are a wide range of courses grouped under various departments including social sciences, health sciences and humanities. As of today, the African Development Bank estimates that there are 14 million students in higher education in Africa, representing about $6.4 \%$ of global tertiary education enrolments but less than $25 \%$ of those students are in STEM fields, with the majority of students studying social sciences and humanities (Campos, 2018). Government money is spent on development and security, not research and innovation. According to the World Economic Forum, Africa produces only $1.1 \%$ of global scientific knowledge. The continent has just 79 scientists per million of inhabitants compared to countries like Brazil and United States where the ratio stands at 656 and 4,500, respectively. Worst of all, of those scientists and engineers who are trained in Africa, most work elsewhere due to the lack of infrastructure and resources (Kariuki, 2015).

Currently, most African countries face shortages of human resources and capacity within science, technology, engineering, and mathematics as well as agriculture and health disciplines (International Institute for Water and Environmental Engineering 2013; Montenegro and Patrinos 2012; World Bank 2007). The current pattern of skills production in Africa does not match labour market demand or development needs. The recent trend in African higher education is the low percentage of graduates in areas of engineering, agriculture, health, and science. According to the Trends in International Mathematics and Science (TIMS) study and the UNESCO Global Monitoring Reports, the performance of African students in mathematics and science is persistently lower than international averages (Hooker, 2017). Hence, the quality of Science, Technology, Engineering and Mathematics (STEM) education is poor in Africa. Tsupros (2008), postulates that STEM education is an interdisciplinary approach to learning where rigorous academic concepts are coupled with real-world lessons as students apply science, technology, engineering, and mathematics in contexts that make connections between school, community, work, and the global enterprise enabling the development of STEM literacy and with it the ability to compete in the new economy.
According to Brown, Brown, Reardon \& Merrill (2011), STEM education has been defined as "a standards-based, meta-discipline residing at the school level where all teachers, especially science, technology, engineering, and mathematics (STEM) teachers, teach an integrated approach to teaching and learning, where discipline-specific content is not divided, but addressed and treated as one lively, fluid study." Sichangi (2018) posits that STEM education is concerned with educating students on the four specific subjects in an interdisciplinary, and applied approach. The teaching process endeavours to equip learners with knowledge and skills to solve real-life problems through gathering information, synthesizing it and making sense of it and passing value judgement. STEM education begins with proposing real-life situations that are open-ended and related to the concept taught. Learners are given time to analyse, engage and provide solutions to the problems individually and in groups. Science in STEM comprises three related subjects: biology, chemistry, and physics. For instance, when making bottled water, we use chemistry to decide chemical requirements during purification, biology to decide human nutritional requirement from water, and physics to decide package material taking into consideration heat and conduction properties.

Technology in the context of STEM is the application of knowledge and skills to make goods or services to meet a need. Engineering in this case is the application of science and mathematics to solve problems. Bottling water through purification process, determining nutritional value, and packaged in the right type of bottle is the process of engineering. Campos (2019) posits that over the past several decades, it has become apparent that STEM is an important determinant of a country's economic development and security. Countries that have invested in STEM have experienced global prominence. Studies estimate that between 50 to 85 percent of U.S. GDP growth in the past 50 years can be attributed to advancements in science and engineering. The need for strengthening of Africa's economy, boosting growth and development, raising the standard of living and repositioning the continent to be at par with the global economy in trade, manufacturing, technology, agriculture, innovation and several other areas has led to the ongoing STEM conversation and transformation effort.

Despite some investments in STEM research and education, Africa has a critical shortage of highly trained scientists, technologists, engineers, and innovators with enrolments in STEM programmes and falls behind global averages 
International Journal of Engineering Research and Technology. ISSN 0974-3154, Volume 13, Number 7 (2020), pp. $1516-1524$

(C) International Research Publication House. https://dx.doi.org/10.37624/IJERT/13.7.2020.1516-1524

(Mukeredzi, 2019). For example, the African Capacity Building Foundation has estimated the continent suffers from a shortage of over eight million medical doctors and specialists, over one million researchers, over four million engineers and nearly 70,000 agricultural scientists and researchers.

The economist (2019) posits that there are fewer than 2,000 colleges and universities on a continent with a billion people in 55 countries. Less than $7 \%$ percent of Africans have college degrees compared to $30 \%$ of North Americans and Europeans and more than half of Africa's population is under the age of 30. There are a wealth of comparative indicators that illustrate how Africa lags behind other regions of the world in scientific productivity and knowledge systems. Problems with higher education institutional infrastructure inputs are also well documented - these include issues such as electricity and water supply, staff shortages and ever-increasing enrolment due to fast-growing youth population, research infrastructure, weak governance and quality assurance, and the many material challenges to Higher Education Institutions in Africa. After some 16 years of subsidized public education, these graduates face unemployment rates of up to $90 \%$ in some instances, while their countries continue to transfer major resources to expatriate countries for construction and maintenance of its public infrastructures because of the lack of a competent domestic STEM workforce; and at the end, the continued lack of domestic expertise means African countries cannot maintain their own infrastructures or develop new industries, lest they bring back the expatriates at more cost. For example, Nigeria requires 51,000 more engineers in its electric power infrastructure than it currently produces (Khumbah, 2018). Subsequently, we will critically examine the role of higher education in advancing Africa's STEM agenda, the role of government and the private sector, the importance of STEM education to Africa, challenges faced in the ongoing quest to strengthen Africa's position via STEM education and propose strategies for overcoming these difficulties.

\section{LITERATURE REVIEW}

The projections for 2020 in Africa promise enormous growth in the areas of global electrification, solar energy, telecommunications, healthcare and the internet of everywhere'. Career wise the future is very bright as well, Campos (2018). In his opening address at the Pan African Conference on Education in April, the assistant director general for education at the United Nations Educational, Scientific and Cultural Organisation (UNESCO), Firmin Matoko, said: 'We need to help Africa tap into scientific inventions and discoveries that are happening around the world, and step up investments in scientific research to enable Africans to be producers of knowledge rather than consumers by embracing the advancement in technology and equipping the youth with relevant knowledge and skills the 21 st century demands.'

But unfortunately, while non-African countries dedicate up to $4 \%$ of their GDP to scientific research, African countries have allocated little to no funding to science, thus increasing the gap between Africa and other countries in STEM performance and therefore economic development. Those that are skilled often emigrate to other continents to earn their livelihoods in a phenomenon known as "brain drain." This is especially true when it comes to STEM skills. Each year, 70,000 skilled professionals make this exodus. Brain drain diminishes the development of industries like STEM which need highly educated nationals. Due to the lack of a domestic STEM workforce, most STEM jobs in Africa today are outsourced to other countries, including the U.S., China, and India. For example, because China has a large workforce of engineers, China has a strong presence in development projects in Africa. (Campos, 2018).

Lillian Barnard, from Microsoft, put it this way, "the biggest challenges South African entrepreneurs face - as well as those looking for work in corporate firms, is a lack of Science, Technology, Engineering and Mathematics (STEM) skills" (Business Tech, 2018). STEM education is lagging in Africa, where many low-income countries (LICs) are found. According to the Trends in International Mathematics and Science (TIMS) study and the UNESCO Global Monitoring Reports, the performance of African students in mathematics and science is persistently lower than international averages (Hooker, 2017). Hence, the quality of STEM education is poor in Africa.

Kigali, (2019) opines that the number and share of young people in tertiary education in sub-Saharan Africa will keep growing. The region has about $90 \mathrm{~m}$ people aged $20-24$, a figure projected to double over the next 30 years. If African countries are to meet the aspirations of educated young people, they must ensure there are opportunities for further study. With the public sector struggling to meet demand for places and to offer a high-quality education, the private sector is filling the gap. From 1990 to 2014 the number of public universities in sub-Saharan Africa rose from 100 to 500, while private universities grew from 30 to more than 1,000. Clay (2016) postulates that Africa's challenge is how to create a strong higher education sector to prepare a new generation of leaders in the professions, business, and civil society. This is necessary because the continent has long struggled with how to create and deliver quality tertiary education to its young people.

Despite some investments in STEM research and education, Africa has a critical shortage of highly trained scientists, technologists, engineers, and innovators with enrolments in STEM programmes and falls behind global averages (Mukeredzi, 2019). For example, the African Capacity Building Foundation has estimated the continent suffers from a shortage of over eight million medical doctors and specialists, over one million researchers, over four million engineers and nearly 70,000 agricultural scientists and researchers. According to Kigali (2019) there are fewer than 2,000 colleges and universities on a continent with a billion people in 55 countries. Less than $7 \%$ percent of Africans have college degrees compared to $30 \%$ of North Americans and Europeans and more than half of Africa's population is under the age of 30 .

Khumbah (2018) posits there are a wealth of comparative 
indicators that illustrate how Africa lags behind other regions of the world in scientific productivity and knowledge systems. Problems with higher education institutional infrastructure inputs are also well documented - these include issues such as electricity and water supply, staff shortages and everincreasing enrolment due to fast-growing youth population, research infrastructure, weak governance and quality assurance, and the many material challenges to Higher Education Institutions in Africa. while the proportion of students in STEM averages less than 25 percent. After some 16 years of subsidized public education, these graduates face unemployment rates of up to $90 \%$ in some instances, while their countries continue to transfer major resources to expatriate countries for construction and maintenance of its public infrastructures because of the lack of a competent domestic STEM workforce; and at the end, the continued lack of domestic expertise means African countries cannot maintain their own infrastructures or develop new industries, lest they bring back the expatriates at more cost. For example, Nigeria requires 51,000 more engineers in its electric power infrastructure than it currently produces.

In a world where digital connection removes some barriers to innovation such as distance and physical isolation, Africa is isolated from the most important market - that of talent and knowledge generation. Those outside with resources can engage Africa but without knowledge and resources, Africa cannot move itself into the global economy. It will be important that Africa owns, develops, manages, and deploys its talent both to advance its own development and to be among the global players in the science and technology domains as diverse as agriculture and medicine on the one hand, and climate change and business management, on the other.

Khumbah (2018) argues heavy reliance on international expertise and funds results in STEM development in Africa being shaped mostly by international donor and bilateral and multilateral partnerships (e.g. US-based Foundations, the European Union-Africa Joint Strategy, the India-Africa Science and Technology Initiatives and the China-Africa Science and Technology Partnership). While these instruments bring much-needed goodwill, expertise and finances in support of African development, and with over half of all STEM funding coming from international partners, most current implementation mechanisms are not structured to promote African ownership, accountability and sustainability.

The heavy influence of international agencies on STEM activity in Africa also tends to fragmentize inter-African research communities, with each of the sub-regions collaborating more with international partners and less with one another, as measured through their publications output. Inter-African collaborations (collaborations without any South-African or international collaborator) comprise just 2\%, $0.9 \%$ and $2.9 \%$ of all East African, West \& Central African, and Southern African total research output, respectively.

If Africa is to realize its aspirations contained in the African Union's continental agenda 2063 and Science, Technology, Innovation Strategy for Africa (STISA), its governments have to forcefully revitalize their higher education systems towards
STEM Education, as the next - even pivotal - frontier in the continent's historical evolution. It is the calibre of its university graduates in STEM fields that will produce and manage the knowledge that will give relevance to its other institutions - governance, trade, defence, agriculture, health, finance, energy and diplomacy. It is through a vitalized STEM Education that Africa may turn its increasing demographics into a dividend to enhance its democracies.

The figures are stark, and the task of developing African science and its future scientists is daunting. Worst of all, of those scientists and engineers who are trained in Africa, mostly work elsewhere due to the lack of infrastructure and resources. Kariuki (2015).

\section{Obstacles Hindering the transformation of STEM in Africa.}

It is well known that Africa's long-term economic prospects are being constrained by severe skills shortages in many vital sectors, however, one of the areas that requires immediate attention is STEM (science, technology, engineering and mathematics). If Africa does not start building capacity in these subjects, its progress towards achieving sustainable and comprehensive growth will be severely challenged (Yusuf, 2018). According to the business year (2018) the continent potentially contains some of the world's fastest-growing economies, but it can only compete with the rest of the world if it invests in STEM education for young people.

Many African countries face significant challenges in their quest to improve STEM education due to a number of reasons, some of which include; inadequate facilities and basic amenities like electricity, restricted access to education, poor learning outcomes, low salaries of faculty, lack of research funding and equipment, as well as limited autonomy. These issues provide disincentives for professors to stay in African universities. limited educational infrastructure, staff shortages, lack of electricity and water supply, low student attendance in school, weak governance, and lack of materials are other challenges that are hindering efforts to improve STEM education across Africa. There is also the problem of limited research collaboration across STEM fields; Many STEM educators have failed in their efforts to collaborate with other STEM educators that teach other STEM disciplines. This has resulted in poor skill development in giving learners adequate sense of direction and purpose for effective learning and choice of career in STEM related fields. Since STEM education is an integration of many disciplines with their differences and similarities, a normal approach to teaching and learning should be devised through collaboration of the educators involved. Research collaborations through cluster concept across STEM fields for integrated curriculum will enhance connectivity and information sharing among the stake holders. Therefore, all efforts should be made to foster increase in research collaboration among educators and partnership with the industry personnel. Poor Content Is another obstacle. In order to attract and retain a new generation of learners, engineering and technology curricula need to be renovated to optimize the skills that are relevant today. All new teaching materials should provide clear guidelines for all anticipated workload and classroom 
activities. STEM educators and students will benefit from explicit outcomes for courses, assignments, and projects. When specific and clear outcomes are identified, not only can the instructors focus their instruction on specific knowledge, but they can also link their knowledge assessment directly to the outcomes. Poor Condition of laboratory facilities and instructional media is another hiccup in the path of better STEM education in African higher institutions. Many schools are not equipped with the needed facility structure, tools, equipment and required instructional media. When teaching materials are insufficient, teachers should learn to improvise (Nwanekezi et al., 2010). If changes are implemented as needed in our schools, this will enhance teachers' ability to facilitate learning activities to students, improve academic achievement and increase in state and national test scores (Ejiwale, 2012). Limited hands-on training for students is another barrier to achieving high quality STEM education in African tertiary institutions.

Another feasible approach to implement STEM education successfully is to provide hands-on training. This is an opportunity for engineering students to take practical action for the future. Through this approach, students are going to understand what STEM area careers are by employing the machines used in the laboratories that are just similar to the ones they would use on the job. More important, student will use technology in the way one might if you are working in a STEM profession. In addition, a good internship and cooperative education will be beneficial. (Glasgow, 1997, p. 123).

The lack of investment in the professional development of teachers for strong knowledge base has been attributed to poor student performance. As inspired teaching inspires students, new teachers need professional internships for clinical training following completion of degree. The National Council on Teacher Quality reported that all but a quarter of the studentteaching practices program in 134 educational schools earned a "weak" or "poor" rating (Sawchuk, 2011). Poor preparation and shortage in supply of qualified STEM teachers; the quality of teacher preparation is crucial to helping students reach higher academic standards. Unfortunately, many classrooms today are filled with under-prepared individuals because they have received poor quality training or none at all.

Poor Content delivery and method of assessment also hinders the growth of STEM education in Africa. According to Onuja (1987), the method of teaching determines the amount of knowledge that learners acquire. The STEM educator as a facilitator should not only be knowledgeable in the subject but should also possess the basic and necessary skills with which to impact the knowledge of the subjects to the students and learners at all levels of learning (Nwanekezi et al., 2010). When teaching is not effective, the learners grasp little or nothing and this reflects in the future choice of career. This implies that STEM educators should endeavour to understand the available methods and teaching strategies and select from them according to the demand of the lesson at hand with attention to the diverse nature of the students in the classroom, their learning styles and abilities.
There are also concerns about quality arising from a mismatch between demand and supply of qualified teachers and about the gap between science education research findings and what happens in the classroom. There often is an insufficient understanding of the breadth of competences required of teachers and teacher educators for enhancing personal and collaborative achievement, innovation and cultural and economic sustainability.

Insufficient investments in strategic co-operation and development of ecosystems that would foster effective adoption of latest research findings and emerging technologies in industry and enterprise, particularly SMEs.

Inadequate public knowledge about and understanding of the complexities of the scientific and social challenges facing humanity, across Africa and globally. Little involvement of stakeholders in science education policy, research, development and innovation, particularly between students, families, teachers, employers and civil society in the formal education system.

\section{METHODOLOGY}

A systematic literature review was carried out to locate and comprehensively synthesize research on STEM education policies in Sub Saharan Africa, challenges and solutions to prevalent issues crippling STEM education in Africa. This study sought to gain insight as to how Africa's higher education system can be used as a tool to propagate STEM education in Africa. Our findings are systematically documented and solutions proffered to the challenges hindering the advancement of STEM education in African higher institutions.

\section{Inclusion/ exclusion criteria}

Two inclusion criteria were created to screen for relevant studies: (1) published between 2013 and 2020 and (2) contained in the studies keywords or synonyms related to the research questions: (a) STEM, (b) higher education and (c) Africa. The search terms were as follows:

1. STEM OR science OR technology OR engineering OR mathematics

\section{Higher education OR higher institution}

3. Africa

\section{Data screening and extraction}

This approach uncovered a total of 26 articles, all published between 2013 and 2020. 2 of the articles were government agencies report on STEM education policies from Africa, while 24 primary research studies, theoretical analysis, and commentary on STEM education in Africa. Regarding methodology five were qualitative, three were quantitative, two were survey-based, two were qualitative and quantitative, and seventeen were quantitative. Qualitative data is defined by data collection by the means of interviews or open-ended questions in surveys, quantitative data through the observation of students' performances in activities and survey-based data as questions with a Likert scale. 
International Journal of Engineering Research and Technology. ISSN 0974-3154, Volume 13, Number 7 (2020), pp. $1516-1524$

(C) International Research Publication House. https://dx.doi.org/10.37624/IJERT/13.7.2020.1516-1524

\section{Data analysis}

Relevant information from the collected articles were presented according to varying parts of the research questions. STEM education policies outlined in governmental reports from Africa and other countries outside Africa were compared to seek for common similarities and differences. The challenges Africa is facing in STEM education were described and progress made to date were summarized.

\section{FINDINGS}

The findings are divided into two categories: (1) The imperative of STEM education in Africa (2) Transforming STEM education in Africa.

\section{The Imperative of STEM Education in Africa}

The rationale for investment in STEM education relates mainly to its association with improved economic outcomes (African American Institute, 2015; Williams, 2011). There is a wealth of comparative indicators that illustrate how Africa lags behind other regions of the world in scientific productivity and knowledge systems. For example, less than $7 \%$ of Africans have college degrees compared to $30 \%$ of North Americans and Europeans and more than half of Africa's population is under the age of 30 , and only a very small proportion of this figure hold STEM related degrees.

The 21 st century job market requires a new set of skills, and there is more emphasis on STEM skills (Voogt, 2012) which Africa is lacking. STEM education is recommended for bridging the demand and supply of skills in Africa (Burnett, 2012) STEM education is regarded as a priority in high-, middle- and low-income countries (Burnett, 2012). However, STEM education is lagging in Africa, where many lowincome countries (LICs) are found. According to the Trends in International Mathematics and Science (TIMS) study and the UNESCO Global Monitoring Reports, the performance of African students in mathematics and science is persistently lower than international averages (Hooker, 2017) necessitating a STEM education overhaul in Africa.

STEM education is also proposed as a response to depressed economies (Williams, 2011). According to Development Visions, a significant policy document, development in low or lower middle-income countries in sub-Saharan Africa tends to follow similar patterns (Tikly et al., 2018). These countries pursue industrialisation and economic diversification so that their economies can grow (Tikly et al., 2018). STEM can improve competitiveness in the global economy and greater emphasis on it is needed to enhance Africa's global competitiveness (African American Institute, 2015) It also helps curb unemployment which arises because workers do not have the skills required by employers as skills taught in Africa mostly do not match with the requirements of employers (Burnett \& Jayaram, 2012)

The projections for 2020 in Africa promise enormous growth in the areas of global electrification, solar energy, telecommunications, healthcare, and the internet of everywhere - all STEM fields where qualified hands will be needed to achieve the vision. Career wise the future is very bright as well. Campos (2018) opines that STEM has been useful for enhancing teacher training in developing countries, stimulating innovative approaches for education, and aligning the demand and supply of skills (Burnett \& Jayaram, 2012; Hooker, 2017).

In Rwanda, engineering education has provided skilled personnel for industry and solutions for local development problems (Lwakabamba \& Lujara, 2003). In addition, collaboration with Swedish universities has boosted the research capacity at the University of Rwanda (Tvedten, Byabagambi, Lindström, \& Tedre, 2018), this is but a negligent proportion of the work to be done in Rwanda.

Kigali (2019) opines that the number and share of young people in tertiary education in sub-Saharan Africa will keep growing. The region has about $90 \mathrm{~m}$ people aged $20-24$, a figure projected to double over the next 30 years. If African countries are to meet the aspirations of educated young people, they must ensure there are opportunities for further study. With the public sector struggling to meet demand for places and to offer a high-quality education, the private sector is filling the gap. From 1990 to 2014 the number of public universities in sub-Saharan Africa rose from 100 to 500, while private universities grew from 30 to more than 1,000. Africa's challenge is how to create a strong higher education sector to prepare a new generation of leaders in the professions, business and civil society. This is necessary because the continent has long struggled with how to create and deliver quality tertiary education to its young people. There is also the need to transform and support existing institutions in order to broaden the number of quality institutions (Clay, 2016). Developing new talent and creating and transforming existing schools is a big lift.

Despite some investments in STEM research and education, Africa has a critical shortage of highly trained scientists, technologists, engineers, and innovators with enrolments in STEM programmes and falls behind global averages. For example, the African Capacity Building Foundation has estimated the continent suffers from a shortage of over eight million medical doctors and specialists, over one million researchers, over four million engineers and nearly 70,000 agricultural scientists and researchers (Mukeredzi, 2019). Kigali (2019) posits that there are fewer than 2,000 colleges and universities on a continent with a billion people in 55 countries. Of the less than $25 \%$ that enrolled to earn STEM related degrees, these graduates face unemployment rates of up to $90 \%$ in some instances, while their countries continue to transfer major resources to expatriate countries for construction and maintenance of its public infrastructures because of the lack of a competent domestic STEM workforce; and at the end, the continued lack of domestic expertise means African countries cannot maintain their own infrastructures or develop new industries, lest they bring back the expatriates at more cost. For example, Nigeria requires 51,000 more engineers in its electric power infrastructure than it currently produces (Khumbah, 2018).

Furthermore, the increasingly technical nature of many public and private sector international negotiations on subjects 
pertinent to Africa's development and security - such as climate change, trade and finance - favours countries that use advanced scientific knowledge to inform their positions, further constraining Africa's position in international affairs and trade. In a world where digital connection removes some barriers to innovation such as distance and physical isolation, Africa is isolated from the most important market - that of talent and knowledge generation. Those outside with resources can engage Africa but without knowledge and resources, Africa cannot move itself into the global economy. It will be important that Africa owns, develops, manages, and deploys its talent both to advance its own development and to be among the global players in the science and technology domains as diverse as agriculture and medicine on the one hand, and climate change and business management, on the other.

Khumbah (2018) argues that heavy reliance on international expertise and funds results in STEM development in Africa being shaped mostly by international donor and bilateral and multilateral partnerships (e.g. US-based Foundations, the European Union-Africa Joint Strategy, the India-Africa Science and Technology Initiatives and the China-Africa Science and Technology Partnership). While these instruments bring much-needed goodwill, expertise and finances in support of African development, and with over half of all STEM funding coming from international partners, most current implementation mechanisms are not structured to promote African ownership, accountability and sustainability.

The heavy influence of international agencies on STEM activity in Africa also tends to fragmentize inter-African research communities, with each of the sub-regions collaborating more with international partners and less with one another, as measured through their publications output. Inter-African collaborations (collaborations without any South-African or international collaborator) comprise just $2 \%$, $0.9 \%$ and $2.9 \%$ of all East African, West \& Central African and Southern African total research output, respectively.

If Africa is to realize its aspirations contained in the African Union's continental agenda 2063 and Science, Technology, Innovation Strategy for Africa (STISA), its governments have to forcefully revitalize their higher education systems towards STEM Education, as the next - even pivotal - frontier in the continent's historical evolution. It is the calibre of its university graduates in STEM fields that will produce and manage the knowledge that will give relevance to its other institutions - governance, trade, defense, agriculture, health, finance, energy and diplomacy. It is through a vitalized STEM Education that Africa may turn its increasing demographics into a dividend to enhance its democracies.

The figures are stark, and the task of developing African science and its future scientists is daunting. Government money is spent on development and security, not research and innovation. According to the World Economic Forum, Africa produces only $1.1 \%$ of global scientific knowledge. The continent has just 79 scientists per million of inhabitants compared to countries like Brazil and United States where the ratio stands at 656 and 4,500, respectively. There are just 79 scientists per million Africans, compared to 4,500 per million people in the United States. Worst of all, of those scientists and engineers who are trained in Africa, mostly work elsewhere due to the lack of infrastructure and resources. (Kariuki, 2015). A workforce with the ability to apply critical thinking, creativity, and innovation to create applications that can be commercialized and create jobs is indeed a desire for all countries globally. Concerns have been raised by prominent institutions on Africa's inability to fill most STEM jobs within industries. The shortage of such workforce is linked to classroom teaching and learning practices that are pre-dominantly geared towards passing examinations, and not towards applying knowledge acquired to solve real life problems affecting societies. (Sichangi, 2018).

\section{TRANSFORMING STEM EDUCATION IN AFRICA}

It has become the general consensus that for any meaningful and sustainable economic growth to be realised STEM education must be centrally placed in the development agenda of nations. Outlined are some necessary steps for STEM education transformation. Adoption of favourable policies: Successful implementation of the STEM agenda in higher institutions greatly depends on various education and economic policies a country adopts that is why key policies and investments are necessary to unlock Africa's potential. Meanwhile, Africa does not have a robust strategic plan on STEM policies, or even a clear framework for implementing them. It is not even clear if some national leaders understand their importance. There is a need for government to put in place policies that encourage students to embrace and explore STEM subjects so they can potentially fill the skills gap in the science, engineering and tech industries, apply their skills to developing scalable solutions to local and global challenges and ensure improved quality of life and Socio-economic development.

Resources and support: the government and private sector should also provide accessible resources and opportunities to tertiary institutions to carry out STEM related research and gain practical experience from helping proffer solutions to real world problems. Maintaining a robust STEM curriculum: there is a need to regularly update the STEM curriculum to reflect current trends in innovation. To meet future demand machinery has to be put in place to accommodate the rapid technological changes now being experienced by providing long life learning where essential skills are taught. Introducing an innovative approach to teaching and learning should be prioritized. Quality assurance test results reveal 96\% of respondents who studied engineering abroad are satisfied with the quality of education they received while only $14 \%$ their Nigeria-trained counterparts were satisfied with the quality of education they received in Nigeria necessitating the need for a thorough over haulage of the syllabus and entire teaching system.

Ndalichako (2018) posits that for Africa to fully benefit from, and cope with technological transformation, universities must adopt research-based education to improve the quality and quantity of STEM education, systematically scale up support to STEM disciplines, maximise the use of digital technology. Continuous modification of curricula: African universities 
have undertaken to review their science, technology, engineering and mathematics (STEM) related curricula extensively every three to five years to respond to the everchanging needs of society - and to prepare a critical mass of youth with the skills needed to promote research and innovation for the continent's industrialisation. The stand was one of several resolutions adopted at the Seventh African Regional Conference of Vice-Chancellors and Deans of Science Education, Engineering and Technology held in Zimbabwe, nearly 60 vice-chancellors and deans of science, engineering and technology, people responsible for teaching policy in universities across Africa, attended the conference (Mukeredzi, 2019). Professor Eddie Mwenje, vice-chancellor of Bindura University of Science Education, said "universities have resolved to improve the integration of information communication technology in university teaching, have blended learning; that means we have to do the traditional face-to-face teaching but we ought to ensure that universities also include and adopt e-learning in their teaching" (Mukeredzi, 2019, p2)

Other resolutions included amplifying universities' linkage with industry to strengthen curricula and research programmes, thereby making them more relevant to the needs of society. Ndalichako (2018) postulates that bridging Africa's technological gap will require concerted efforts to reform Africa's innovation system and STEM education by making it more entrepreneurial and market oriented. The government of Nigeria has already forged partnerships and is drawing upon the technological experience of other countries to build new STEM learning opportunities for Nigerian students. GPE has allocated more than US\$100 million in grants to Nigeria in an effort to improve the quality of education. Today, Nigerian educators are looking to take the next step and improve STEM education by using its international connections to install rigorous curriculums and increase knowledge transfers. (Tby, 2018)

Educationionists, government and corporations seem increasingly focused on encouraging students' interest through innovative and relatable STEM initiatives including experimentation, robotics, coding, or even low-tech group activities that model the experience of solving engineering problems in the real world as well. Classrooms need to offer teaching and learning processes that have real impact on these disciplines in daily life and specifically in Africa. Upgrading of STEM curriculum will transform the way learners understand the world environment, giving them a more sensible outlook of everything and a practical approach to real-life experiences as well as problems and solutions. This approach of teaching STEM subjects is realizable if teachers are trained and supported to achieve behaviour changes. Curriculum reform needs to go hand-in-hand with continuous teacher professional development. These kind of curriculum reforms require support by all stakeholders including the parents. (Sichangi, 2018)

Create centres of excellence: resources in many of Africa's universities are already stretched and covering a wide range of subjects does little to help the situation. Centres of excellence can provide leadership, best practices, and research, among others, in a specific field. This allows institutions to focus their resources on a handful of key areas, and the pooled funding results in better resources and improved facilities. By addressing regional challenges these centres can establish a sustainable business model, and their graduates can have a direct impact on improving their local community.

"Governments need to invest in education and create a legislative framework, which allows tertiary education, particularly in STEM subjects, to prosper" (Hambly, 2016). The Institute of Mathematics and Physics at the University of Abomey-Calavi in Benin has done just this. The institution's mission is to equip Africa with young scientists who can become future teachers in the field, to promote cooperation and partnerships in research and training within the continent, to prevent scientists from leaving the continent and contributing to so-called 'brain drain' (Hambly, 2016). Keep improving digital technology: Technological advances have had a huge impact on learning across Africa. Online learning platforms, including mass open online courses, or MOOCs, have the potential to revolutionise education, with students able to access high quality learning materials regardless of their geographic location, if they can connect to the internet. Improve links with tech hubs: Tech hubs in Africa have been popping up at a considerable rate, and in all corners of the continent. Aside affording users (startup owners and entrepreneurs) a unique opportunity to grow and develop their business and ideas, it also exposes them to the latest tool in the industry at a pocket-friendly cost.

Measure performance and labour markets: for education to be effective, institutions should regularly monitor and evaluate their programmes. Information about the local labour market should be used to determine the needs of local regions and the relevance of the institution's curriculum in being able to meet these demands. Regular inspection of other standards can ensure universities are maintaining a high level of quality and efficiency. There are a number of organisations in Africa that gather data which can be used by universities, enabling them to effectively evaluate their programmes without putting a huge burden on their already limited resources. The African Capacity Building Foundation is one such organisation, which works with a number of multilateral partners, African and non-regional partners to provide capacity building data. This 'knowledge hub' publishes and disseminates regular reports on the state of play across the continent. Resources such as this can help universities and other educational institutions to tailor their programmes to the needs of specific regions and sectors, without having to do the groundwork themselves (Hambly, 2016).

Increase links to private sector given that the private sector is the continent's main source of job creation, it could help universities to establish how best to equip Africa's youth with the skills needed to enter the work. An example of a partnership in action is that of Hecate Energy Africa and two universities in Tanzania. The company has joined with the University of Dodoma and the Nelson Mandela African Institute of Science and Technology to implement undergraduate and graduate programmes in the field of renewable energy. The aim of this collaboration is to increase access to clean and reliable power in Tanzania, and the wider region, and it will harness the talents of their students to do so. 
International Journal of Engineering Research and Technology. ISSN 0974-3154, Volume 13, Number 7 (2020), pp. 1516-1524

(C) International Research Publication House. https://dx.doi.org/10.37624/IJERT/13.7.2020.1516-1524

For the continent to prosper, it is essential that 'Generation Science' - the generation empowered by an understanding and appreciation of science and technology - succeeds so young people can harness STEM skills to overcome the many challenges facing the region. (Hambly, 2016).

\section{CONCLUSION AND RECOMMENDATION}

The African Union's Science, Technology and Innovation Strategy 2024 places science, technology, and innovation at the epicentre of Africa's socioeconomic transformation and identifies universities as the driving force of a STEM-led revolution. Some of the challenges facing STEM education in Africa include unqualified STEM teachers, high pupil -teacher ratios, unavailability of required resources, and outdated curricula Improving STEM education in Africa will require collaboration between government and the private sector and this study recommends that they provide adequate funding to acquire infrastructure, fund research and engage qualified staff Tertiary institutions must also adopt project/result-based learning methods aimed at creating solutions to STEM problems peculiar to our continent and needs, initiate industry-school mentorship programmes, IT training and scholarships which will help encourage students develop their STEM skill sets. Further measures include adoption of favourable policies and research based methodology, adoption of new teaching methods with emphasis on innovation. The government through It's university governing body and the ministry of education should embark on advocacy to educate the public on the potential role of STEM education in national economic development Promoting better STEM education in our higher institutions will be the catalyst needed to set Africa on the path to economic recovery and global competitiveness.

A thorough revamping of STEM education in Africa with our tertiary institutions taking the lead is most likely to succeed if four keywords are the focus point: project-based partnership, mentorship, research, and innovation. On Project Based Partnership: Collaborative global learning should be introduced where students access current STEM inventions and innovations via the internet in partner institutions, industries and research facilities all over the world and are graded based on their ability to reproduce and improve on simple projects every semester for the duration of their programme. This builds up students' global competence and ensures only relevant knowledge is assimilated and improved upon. Mentorship should take the form of a volunteer industry expert sourced by the institution and assigned to guide a small group of students from first year to graduation. Training them on current innovations with a grading system based on innovation level and research skills assessed through yearly small-scale projects carried out to encourage students to be innovators and inventors thereby moulding them to be problem solvers and researchers. The uniqueness of this system lies in the one on one student to expert accessibility and grades majorly based on consistent projects that solve a need, build inventiveness and good research ethics.

\section{REFERENCES}

Campos, Z . (Forbes 2019) How focusing on education in Africa can help raise young, successful entrepreneurs. Retrieved from: https://www.google.com/amp/s/www.forbes.com/sites/they ec/2019/10/15/how-focusing-on-education-in-africa-canhelp-raise-young-successful-entrepreneurs/amp/

Clay, P. (2016) It's Africa's time to rise: let's end our academic isolation. Retrieved from:

https://www.theguardian.com/science/blog/2016/mar/07/itsafricas-time-to-rise-lets-end-our-academic-isolation

Ejiwale, J. (2013) Barriers to Successful Implementation of STEM Education. retrieved from:

https://www.semanticscholar.org/paper/Barriers-toSuccessful-Implementation-of-STEM-

Ejiwale/50a4b1519cf02f279cf9ea120993d2a991c0bfce

GSDRC Publication (2019) Benefits of STEM education. Retrieved from: https://gsdrc.org/publications/benefits-ofstem-education/

Hambly, S. (2016) Seven ways to improve Africa's STEM education. Retrieved from:

https://www.scidev.net/sub-saharan-africa/opinion/ways-toimprove-africa-s-stem-

education.html?_cf_chl_jschl_tk__=b1b74d8fb4ad20ac7e a79abfadb3bcbdb638c15f-1580972966-0-AROIPoknwkFeps8WPZHkQoP3mw3O_gJk4QJa23AGHV6XeBqOtDLy EBk0fjzTW7F2giTdNz5UpV_iuLrvbTDXEJbYd1Gy4fUF YrVlz5WKFuL3dNpX0YyETsiqJ2Cf1 YPEsMHvWIN36Q h2jIeeNNokU-

MnzxOJExf0iafZfFaEk41mLJnKRIXuuC1fjHFw0_jAwIV U--11KPanr0JvnpP2g6dK-

jSFyxSvdffOfGPGrnIhfy7eJcViSd4Co7zwETwzUK3QwRj 12CmM4j6RgMNiY7Ws3tI1uU0eHNpWkzNVhiT9QyFikLnIh2osc73IXKNX179VfgVYMEHMyYIqCIRS0u7ejMK3 t1W_-b-_URSnv1

Khumbah, N. (2018) Stem education and African development. Retrieved from:

http://africapolicyreview.com/2018/03/07/stem-educationand-african-development/

Kariuki, Tom (2015) Africa produces just 1.1\% of global scientific knowledge - but change is coming. Retrieved from: https://www.theguardian.com/global-developmentprofessionals-network/2015/oct/26/africa-produces-just-11of-global-scientific-knowledge

Kigali. The economist. (Aug 2019) Tertiary education in Africa: A booming population is putting strain on Africa's universities. Retrieved from:

https://www.economist.com/middle-east-andafrica/2019/08/10/a-booming-population-is-putting-strainon-africas-universities.

Kelly Chibale (2015) Higher Education in Africa: Our continent needs science, not aid. Retrieved from: 
International Journal of Engineering Research and Technology. ISSN 0974-3154, Volume 13, Number 7 (2020), pp. 1516-1524

(C) International Research Publication House. https://dx.doi.org/10.37624/IJERT/13.7.2020.1516-1524

https://www.theguardian.com/global-developmentprofessionals-network/2015/jul/02/higher-education-inafrica-science-not-aid

Khumbah, N. (2014) Africa needs science, not aids. Retrieved from:

https://www.google.com/url?q=https://www.nytimes.com/2 014/08/01/opinion/africa-needs-science-notaid.html\&sa $=$ U\&ved=2ahUKEwiow4b0m7HnAhUJT8AK HbDgB4kQFjAKegQIBBAB\&usg=AOvVaw1YlOma4He BGQ4imbQqQFhx

Khumbah, N. (2018) Stem education and African development. Retrieved from:

http://africapolicyreview.com/2018/03/07/stem-educationand-african-development/

Igi-global.com (2020) What is higher education? Retrieved from: https://www.igi-global.com/dictionary/constructingcommunity-higher-education-regardless/13094

Kigitho, W. (2018) Higher education - Caught in a double bind. Retrieved

from:https://www.universityworldnews.com/postmobile.php?story=20180328162530835

Mackie, C. (2019) Developing a high functioning stem community retrieved from:

https://www.google.com/amp/s/www.forbes.com/sites/calvi nmackie/2019/08/28/how-to-develop-a-high-functioningstem-community/amp/

Mukeredzi, T (2019) African vice-chancellors agree to review STEM curricula.

retrieved from: https://www.universityworldnews.com/postmobile.php?story=20191125124727355

Nasir, B. (2019) African vice-chancellors agree to review STEM curricula retrieved from:

https://nasirbaba.online/african-vice-chancellors-agree-toreview-stem-

curricula/?utm_source=rss\&utm_medium=rss\&utm_campai gn=african-vice-chancellors-agree-to-review-stem-curricula

Pols, T. (2019) STEM Education: Science, Technology, Engineering, Maths for South African Underprivileged Schools. Retrieved from:

http://www.samefoundation.org.za/stem-education-sciencetechnology-engineering-maths-for-south-africanunderprivileged-schools/

Sichangi, M.(2018) How science education can unlock Africa's potential. retrieved from: http://www.adeanet.org/en/blogs/how-science-educationcan-unlock-africa-s-potential

The business year (2018) Nigeria embraces STEM education to meet the needs of its population. retrieved from: https://www.thebusinessyear.com/nigeria-2018/stemto-roots/focus
Baani Arora (2019) STEMpedia. STEM Education in Africa - the Past, Present, and Future. Retrieved from: https://www.google.com/amp/s/thestempedia.com/blog/ste m-education-in-africa-the-past-present-and-future/amp/

https://www.thebusinessyear.com/nigeria-2018/stem-toroots/focus

Tikly, L. Joubert, M. Mbogo , A. Bainton, D, Cameron, L \& Doyle, H. (2018) Supporting Secondary School STEM education for Sustainable development in Africa. Retrieved from:

https://www.google.com/url?q=https://www.bristol.ac.uk/m edia-

library/sites/education/documents/Supporting\%2520Second ary $\% 2520$ School $\% 2520$ STEM $\% 2520$ Education $\% 2520$ for $\%$ 2520Sustainabale \%2520Development $\% 2520 \mathrm{in} \% 2520$ Afric a.pdf\&sa $=U \& v e d=2$ ahUKEwjOuJDOoLHnAhULYsAKHc uXBpAQFjAAegQICRAB\&usg=AOvVaw2cDOr_Bb5jM WUYxeVtOYCp

UNESCO (2017) retrieved frrom:

http://www.unesco.org/new/en/dakar/education/highereducation/

UNESCO. retrieved from:

http://uis.unesco.org/en/topic/education-africa

Mba, J. (2018) Challenges and prospects of Africa's higher education. Retrieved from:

https://www.globalpartnership.org/blog/challenges-andprospects-africas-higher-education

SciDevNet (2014) Making higher education work for Africa: Facts and figures. Retrieved from: http://www.africaneconomicoutlook.org/en/theme/youth_e mployment/education-skills-mismatch/

Yusuf, K. (2018) Lack of STEM education is holding back growth and opportunities in Africa. First published in: Accounting business magazine. Retrieved from: https://www.accaglobal.com/africa/en/member/member/acc ounting-business/2018/06/insights/stem-education.html 